\title{
Experimental Rearing of Spiny Lobster, Panulirus homarus (Palinuridae) in Land-Based Tanks at Mirbat Station (Sultanate of Oman) in 2009-2010
}

\author{
Mohammed Balkhair*, Ali Al-Mashiki, and Mikhail Chesalin
}

Fisheries Research Center-Salalah, Ministry of Agriculture and Fisheries Wealth, P.O. Box 33, PC 217, Salalah, Sultanate of Oman
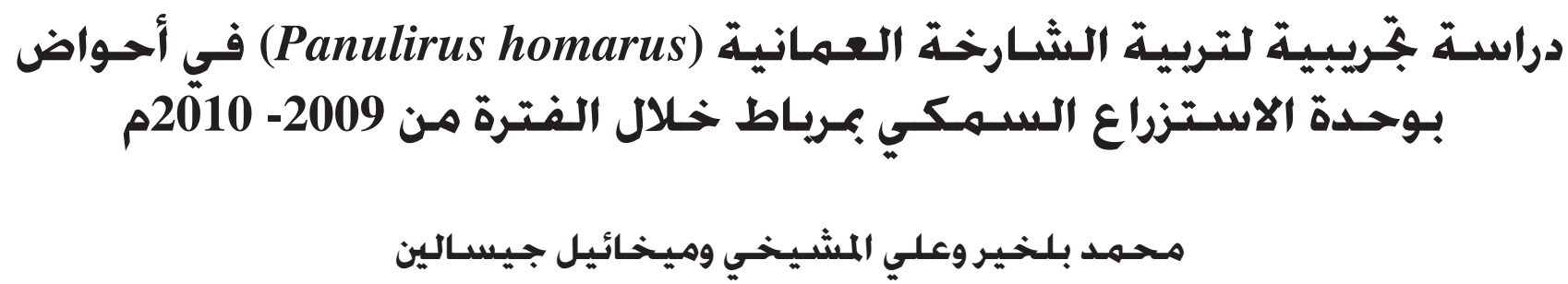

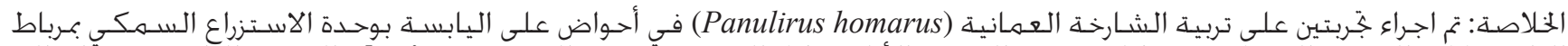

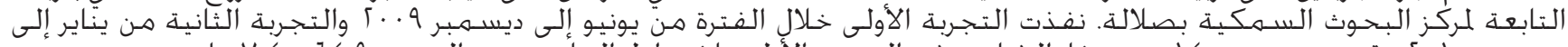

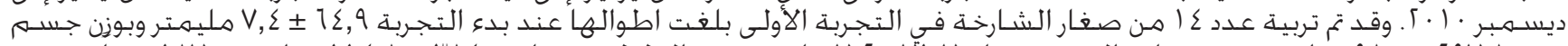

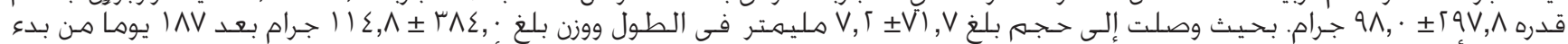

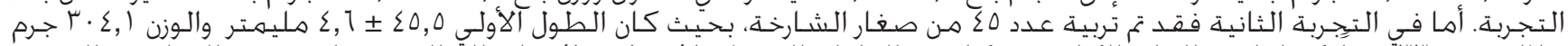

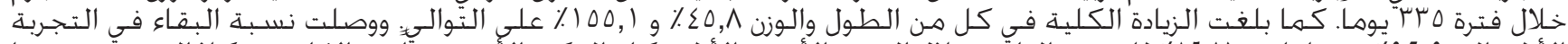

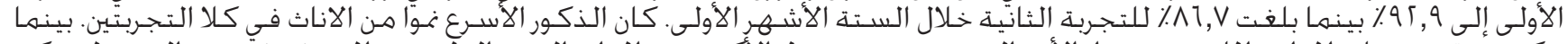

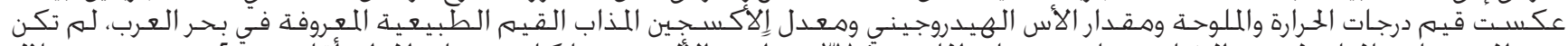

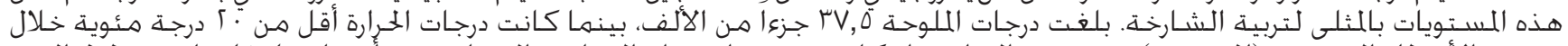

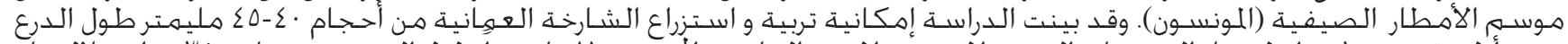

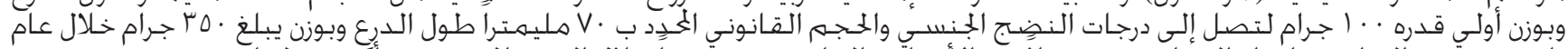

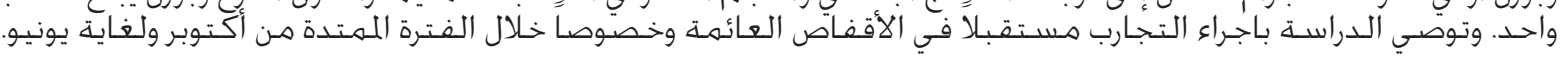

كلمات مفتـاحية: عـمان، أحواض، تربية، الشـارخـة، معدلات النمـو، نسـب البقـاء، الانسـلاخ، التغذية، Panulirus homarus.

ABSTRACT: Two experiments on the rearing of the spiny lobster Panulirus homarus were conducted in land-based tanks at Mirbat Aquaculture Unit from June to December 2009 and January-December 2010. In the first experiment 14 lobsters with an average size of $64.9 \pm 7.4 \mathrm{~mm}$ CL and weight of $297.8 \pm 98.0 \mathrm{~g}$ were reared to an average of $71.7 \pm 7.2 \mathrm{~mm}$ CL and weight of $384.0 \pm 114.8 \mathrm{~g}$ over $187 \mathrm{days}$. In the second experiment 45 lobsters were reared from an initial length of $45.4 \pm 4.6 \mathrm{~mm} \mathrm{CL}$ and weight of $118.9 \mathrm{~g}$ to a length $66.0 \pm 7.1$ $\mathrm{mm} \mathrm{CL}$ and a weight of $304.1 \mathrm{~g}$ over 335 days. Total length increment was $45.8 \%$ and weight increment $155.1 \%$. The daily food ration was $3.0-8.8 \%$. The survival rate in the first experiment was $92.9 \%$, in the second experiment it was also high (86.7\%) during the first six months. In both experiments males grew faster than females. While the water temperature, $\mathrm{pH}$, salinity and dissolved oxygen reflected the ambient condition of the Arabian Sea, these were not optimal levels for lobsters culture. The salinity was higher (37.5 ppt), while the water temperature was low $\left(<20^{\circ} \mathrm{C}\right)$ during the summer monsoon. The study demonstrated the possibility of cultivating sub-adult lobsters in Oman from $40-45 \mathrm{~mm} \mathrm{CL}$ and $100 \mathrm{~g}$ to maturity stage, obtaining the legal size of $70 \mathrm{~mm}$ CL and a weight of about $350 \mathrm{~g}$ over a year. It is recommended that the next experiment be conducted in floating sea cages from October to June.

Keywords: Panulirus homarus, lobster, experiment, tanks, Oman, growth, survival, molting, feeding.

\section{Introduction}

The Omani lobster fishery in the Arabian Sea is based mainly on the scalloped spiny lobster Panulirus homarus (Linnaeus, 1758). This species is one of the largest among crustaceans: the carapace length (CL) attains $14 \mathrm{~cm}$ and total body length $35 \mathrm{~cm}$ (Al-Abdessalaam, 1995). The spiny lobster lives along the coast, inhabiting shallow waters and tends to shelter in rocky reefs and corals. It is a subject of an artisanal fishery, fishermen catch lobsters by hand and by using traps, nets and spears. The high price of lobsters has encouraged fishermen to aggressively exploit their resources with no concern over their long-term sustainability, and as a result, more small sized lobsters were caught. According to fishery statistics, reported lobster landings from Oman have sharply declined from over $2000 \mathrm{t}^{\mathrm{yr}} \mathrm{r}^{-1}$ in 1980's to 233-478 t. $\mathrm{yr}^{-1}$ in 2000-2007 with a low of $19 \mathrm{t}$ in 2009 (Anonymous, 2006, 2010). An assessment of the lobster fishery in Oman in 2003-2005 (Al-Marzouqi et al., 2007) shows that average lobster size and size at first 
maturity were considerably lower in comparison with data of 1987-1989 (Al-Abdulsalaam, 1989) and 1994-1995 (Mohan, 1997). Present governmental management regulation for lobster fisheries include a 2-month open fishing season (1 March - to 30 April), a minimum legal size of $70 \mathrm{~cm} \mathrm{CL}$, gear restriction allowing only traps and a ban on the retention off egg-bearing females after capture. Therefore, it is highly advisable to organize the mariculture of lobsters for both commercial purposes and stock enhancement to promote the rehabilitation of the natural resource.

The first aquarium project on rearing of the $P$. homarus (Phase I) in Oman was conducted in the Mirbat Aquaculture Unit (MAU) of the Fisheries Research Center-Salalah from May to August 2007 (Al-Marzouqi et al., 2009). Thirty-seven lobsters were placed in tanks and reared for 4 months. The initial mean length of the lobsters was $60.63 \mathrm{~mm} \mathrm{CL}$ and at the end of 4-month period it was $65.06 \mathrm{~mm}$ CL.

This paper describes the results of two experiments that were performed in MAU from June to December 2009 and from January to December 2010.

\section{Materials and Methods}

Phase II of the project on experimental rearing of the scalloped spiny lobster $P$. homarus in aquarium tanks in Mirbat was conducted over two periods: firstly, from 24 June 2009 to 27 December 2009 (187 days) and secondly, from 12 January to 13 December 2010 (335 days). In the first experiment in 2009, 14 lobsters (seven males and seven females) were reared, and in the second experiment, 45 sub-adults (23 females and 22 males). All lobsters were caught near Mirbat by the Fisheries Research CenterSalalah team using traps, then placed in large polythene bags with aerated seawater and transferred rapidly upon capture to the tanks to ensure the maintenance of good condition. The lobsters were placed in fibre-reinforced plastic tanks each with a volume of $2 \mathrm{~m}^{3}$, and provided with artificial shelters (half PVC pipes). Stocking density was 7-8 specimens per $\mathrm{m}^{2}$. To maintain water temperature, salinity, $\mathrm{pH}$ and other parameters reflecting the ambient condition of the Arabian Sea, a flow-through sea-water system was used with water sourced offshore. After filtering, the water passed directly to the tanks. The $\mathrm{pH}$, water temperature, salinity and dissolved oxygen were measured daily with a portable probe unit (YSI 556) to study the rearing regime and its influence on growth rate.

The lobsters were sexed and measured mid-dorsally from the transverse ridge between the frontal spines to the posterior carapace edge within $1 \mathrm{~mm}$ accuracy using a vernier caliper. Total wet weight of all specimens was taken. In the first experiment lobsters were maintained in the tanks for 6 months and were remeasured and weighed each month. To eliminate disturbance in the second experiment lobsters were remeasured and weighed only at the middle stage ( 9 June) and at the end (13 December).
The lobsters were fed daily at 17:00 h with chopped sardine. The food and remains were removed and weighed daily to study the ingestion and the food ration.

The tanks were siphoned daily and cleaned thoroughly once a week. They were covered with plastic corrugated sheeting to avoid growth of filamentous green algae.

Important increments were calculated using the following formulae:

- Total length (and weight) increments = final mean carapace length (or weight) - initial mean carapace length (or weight) $\left(\mathrm{CL}_{2}-\mathrm{CL}_{1}\right)$ or $\left(\mathrm{W}_{2}-\mathrm{W}_{1}\right)$.

- Total relative length (and weight) increments $(\%)=$ (final carapace length (or weight) - initial carapace length (or weight)) x $100 /$ initial carapace length (or weight) $\left(\mathrm{CL}_{2}-\mathrm{CL}_{1}\right) \times 100 / \mathrm{CL}_{1}$ or $\left(\mathrm{W}_{2}-\mathrm{W}_{1}\right) \times 100 / \mathrm{W}_{1}$;

- Monthly length (and weight) increments = (final carapace length (or weight) - initial carapace length (or weight)) / Number of months $\left(\mathrm{CL}_{2}-\mathrm{CL}_{1}\right) / \mathrm{T}$ or $\left(\mathrm{W}_{2}-\mathrm{W}_{1}\right) / \mathrm{T}$;

- Daily length (or weight) increments = final carapace length (or weight) - initial carapace length (or weight) / Number of days $\left(\mathrm{CL}_{2}-\mathrm{CL}_{1}\right) / \mathrm{t}$ or $\left(\mathrm{W}_{2}-\mathrm{W}_{1}\right) / \mathrm{t}$;

- Specific growth rate (SGR, \% of the length (or body weight $)$ per day) $=($ logarithm of final carapace length - logarithm of initial carapace length) x 100 / Number of days $\left(\operatorname{lnCL}_{2}-\operatorname{lnCL} L_{1}\right) \times 100 / t$ or $\left.\ln \mathrm{W}_{2}-\ln \mathrm{W}_{1}\right) \times 100 / \mathrm{t}$.

An ANOVA test was used to identify growth rate differences between males and females (Zar, 1984).

\section{Results}

\section{Water Conditions}

The mean monthly water temperature, dissolved oxygen, salinity and $\mathrm{pH}$ in the rearing tanks are presented in figure $1 \mathrm{~A}, \mathrm{~B}$. Temperature showed a seasonal trend with high values during April-June $\left(27.1-29.1^{\circ} \mathrm{C}\right)$ and October -December $\left(25.1-27.1^{\circ} \mathrm{C}\right)$ and low values between July and September $\left(19.6-22.8^{\circ} \mathrm{C}\right.$ ) (the south-west monsoon season). Salinity was relatively constant at approximately $37.53 \pm 0.24 \mathrm{ppt}$ with a small decrease during the monsoon period (July-September), which corresponds to the season of rain and fog. In contrast, the concentration of dissolved oxygen increased (above $6 \mathrm{ml}^{-1} \mathrm{l}^{-1}$ ) during June-September, probably due to more wind mixing of the surface water layer. In other months it remained less saturated (4.2-5.1 $\left.\mathrm{ml} \cdot \mathrm{l}^{-1}\right)$. The $\mathrm{pH}$ was high, ranging between 8.0 and 10.1 (mean 8.6). It reached its maximum values of 10.1 in December 2009 and 9.8 in June 2010.

\section{Growth and Survival}

During the first experiment from June to December 2009 the mean CL of females increased from 64.5 to $70.1 \mathrm{~cm}$, and weight from 290 to $367.3 \mathrm{~g}$. Males began with an average of CL of $65.4 \mathrm{~cm}$ and weight of $305.6 \mathrm{~g}$. In six months they attained an average CL of $73.7 \mathrm{~cm}$ and weight of $403.5 \mathrm{~g}$ (Fig. 2). 

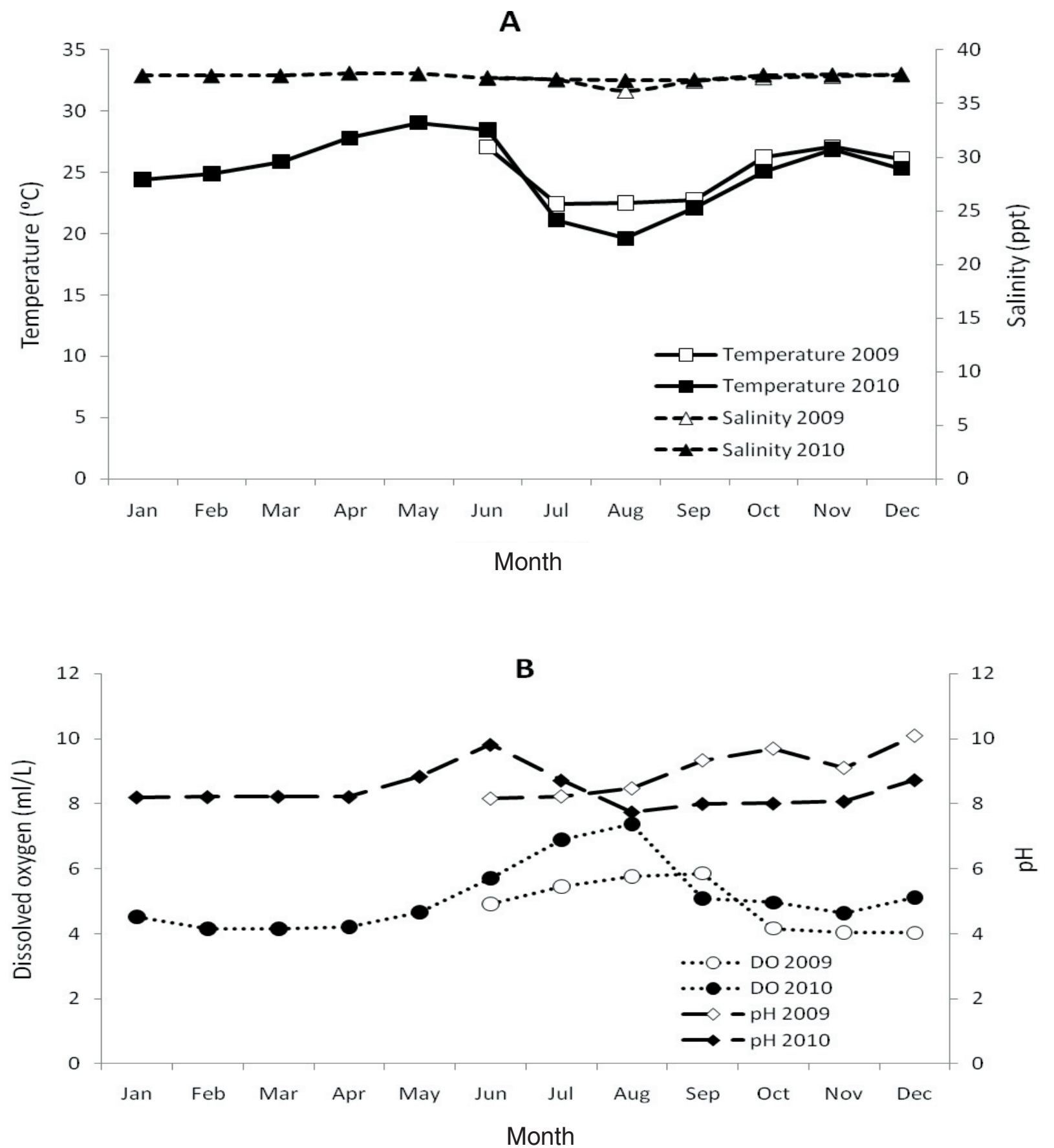

Figure 1. Water condition in the rearing tanks at Mirbat over lobster husbandry during 2009 and 2010: A - temperature and salinity; $\mathrm{B}$ - dissolved oxygen and $\mathrm{pH}$. 

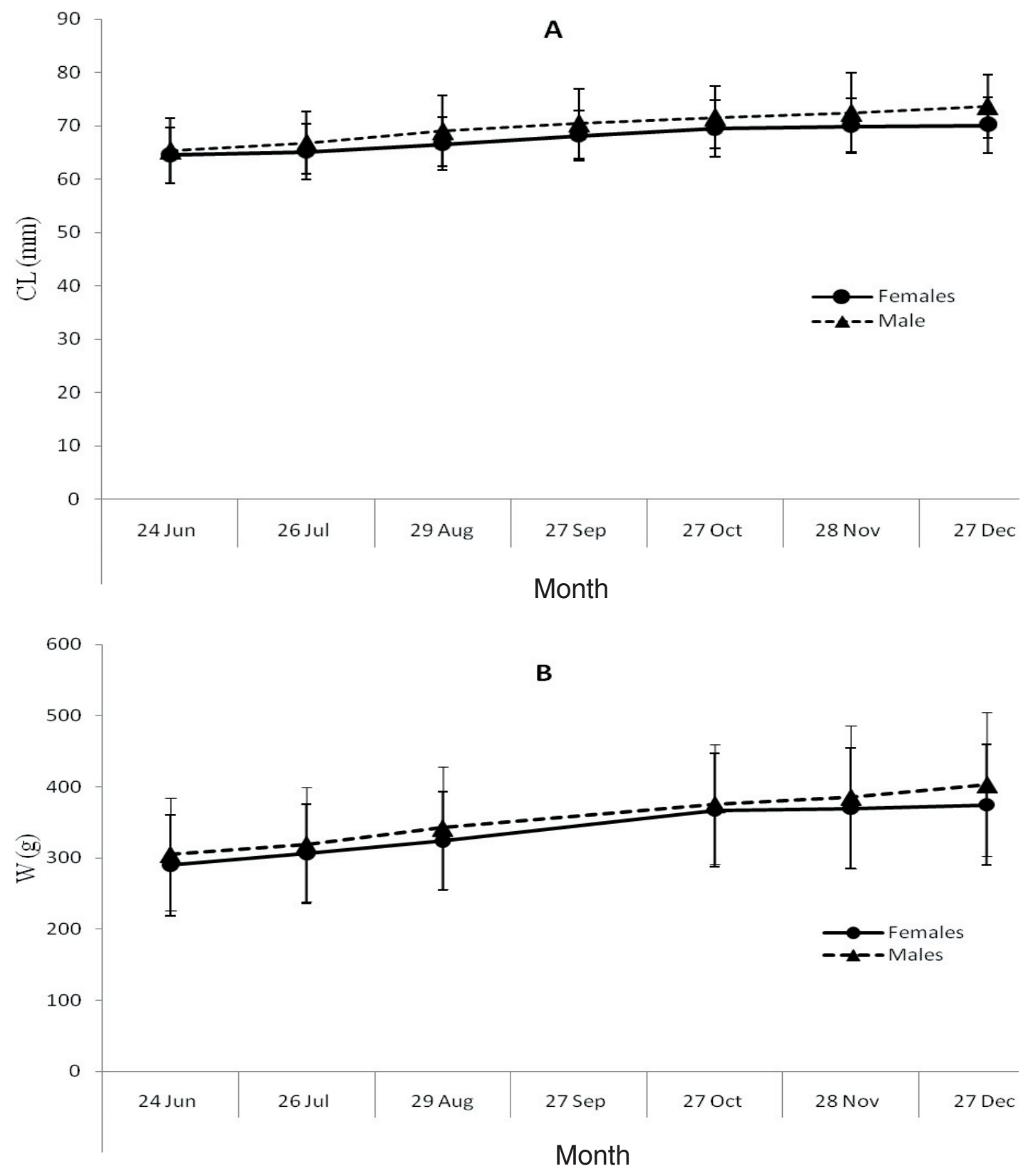

Figure 2. Growth of $P$. homarus males and females in tanks at Mirbat from June to December 2009: A - length, B - weight. 
Table 1. Details on growth increments of the P. homarus during tank culture in Mirbat from June to December 2009 and from January to December 2010.

\begin{tabular}{|c|c|c|c|c|c|c|}
\hline \multirow{2}{*}{ Attribute } & \multicolumn{3}{|c|}{2009} & \multicolumn{3}{|c|}{2010} \\
\hline & Both Sexes & Females & Males & Both Sexes & Females & Males \\
\hline \multicolumn{7}{|l|}{ Total increments } \\
\hline $\mathrm{CL}(\mathrm{mm})$ & 6.77 & 5.62 & 8.31 & 20.7 & 18.3 & 22.5 \\
\hline CL & 10.43 & 8.72 & 12.71 & 45.8 & 39.5 & 50.5 \\
\hline W (g) & 86.22 & 84.81 & 97.92 & 185.1 & - & - \\
\hline $\mathrm{W}(\%)$ & 29.96 & 29.25 & 32.05 & 155.1 & - & - \\
\hline \multicolumn{7}{|c|}{ Monthly increments } \\
\hline CL (mm) & 1.13 & 0.94 & 1.39 & 1.88 & 1.66 & 2.04 \\
\hline W (g) & 14.37 & 14.14 & 16.32 & 16.83 & - & - \\
\hline \multicolumn{7}{|l|}{ Daily increments } \\
\hline CL (mm) & 0.04 & 0.03 & 0.04 & 0.06 & 0.05 & 0.07 \\
\hline W (g) & 0.46 & 0.45 & 0.52 & 0.55 & - & - \\
\hline \multicolumn{7}{|l|}{$\operatorname{SGR}(\%)$} \\
\hline CL $(\%)$ & 0.05 & 0.04 & 0.06 & 0.11 & 0.10 & 0.12 \\
\hline $\mathrm{W}(\%)$ & 0.14 & 0.14 & 0.15 & 0.28 & - & - \\
\hline
\end{tabular}

The mean length increment of both sexes for six months was $6.77 \mathrm{~mm} \mathrm{CL}(10.43 \%)$, and the mean weight increment was $84.81 \mathrm{~g}(29.96 \%)$ (Table 1). Monthly length increments were $0.94 \mathrm{~mm}$ for females and 1.39 $\mathrm{mm}$ for males, weight increments for both sexes was $14.37 \mathrm{~g} \cdot$ month $^{-1}$. The daily weight increment was estimated at $0.46 \mathrm{~g}$ and the specific growth rate (SGR) of weight was $0.14 \%$.

Males grew faster and reached $3.6 \mathrm{~mm}$ larger CL than females over the same period. The ANOVA test show significant differences between the growth rate of males and females in length $\left(\mathrm{F}_{5.12}=6.01, \mathrm{p}<0.05\right)$ and weigth $\left(\mathrm{F}_{5.12}=7.88, \mathrm{p}<0.05\right)$.

The survival rate of the lobsters in this experimental trial was very high; just one male died in November, so the total survival rate during 6 months was $92.9 \%$.

At the beginning of the second experiment 23 females ranged in length from 33.4 to $53.8 \mathrm{~mm}$ CL (mean $44.8 \pm 4.8$ $\mathrm{mm}$ ) and 22 males from 33.4 to $51.1 \mathrm{~mm}$ CL (mean $45.7 \pm 4.4 \mathrm{~mm}$ ) (Table 2). The total weight of all lobsters were

Table 2. Data on number (n), carapace length (CL) and standard deviation (S.D.) of the P. homarus experimental rearing in Mirbat during 2010.

\begin{tabular}{|c|c|c|c|c|c|c|c|c|c|}
\hline \multirow{2}{*}{ Date } & \multicolumn{3}{|c|}{ Both Sexes } & \multicolumn{3}{|c|}{ Females } & \multicolumn{3}{|c|}{ Males } \\
\hline & $\mathrm{n}$ & $\mathrm{CL}(\mathrm{mm})$ & S.D. & $\mathrm{n}$ & $\mathrm{CL}(\mathrm{mm})$ & S.D. & $\mathrm{n}$ & $\mathrm{CL}(\mathrm{mm})$ & S.D. \\
\hline \multirow{2}{*}{12.01 .2010} & \multirow{2}{*}{45} & $45.27 *$ & \multirow{2}{*}{4.59} & \multirow{2}{*}{22} & 44.83 & \multirow{2}{*}{4.82} & \multirow{2}{*}{23} & 45.70 & \multirow{2}{*}{4.43} \\
\hline & & $33.4-53.8$ & & & $33.4-51.1$ & & & $36.7-53.8$ & \\
\hline \multirow{2}{*}{9.06 .2010} & \multirow{2}{*}{24} & 54.43 & \multirow{2}{*}{5.87} & \multirow{2}{*}{11} & 54.11 & \multirow{2}{*}{5.41} & \multirow{2}{*}{13} & 54.68 & \multirow{2}{*}{6.45} \\
\hline & & $43.4-64.7$ & & & $43.4-61.1$ & & & $44.1-64.7$ & \\
\hline \multirow{2}{*}{13.12 .2010} & \multirow{2}{*}{7} & 66.0 & \multirow{2}{*}{7.11} & \multirow{2}{*}{3} & 63.13 & \multirow{2}{*}{8.20} & \multirow{2}{*}{4} & 68.15 & \multirow{2}{*}{6.48} \\
\hline & & $54.3-74.2$ & & & $54.3-70.5$ & & & $60.5-74.2$ & \\
\hline
\end{tabular}

*Above the line is the average. Under the line are the minimum and maximum carapace lengths. 


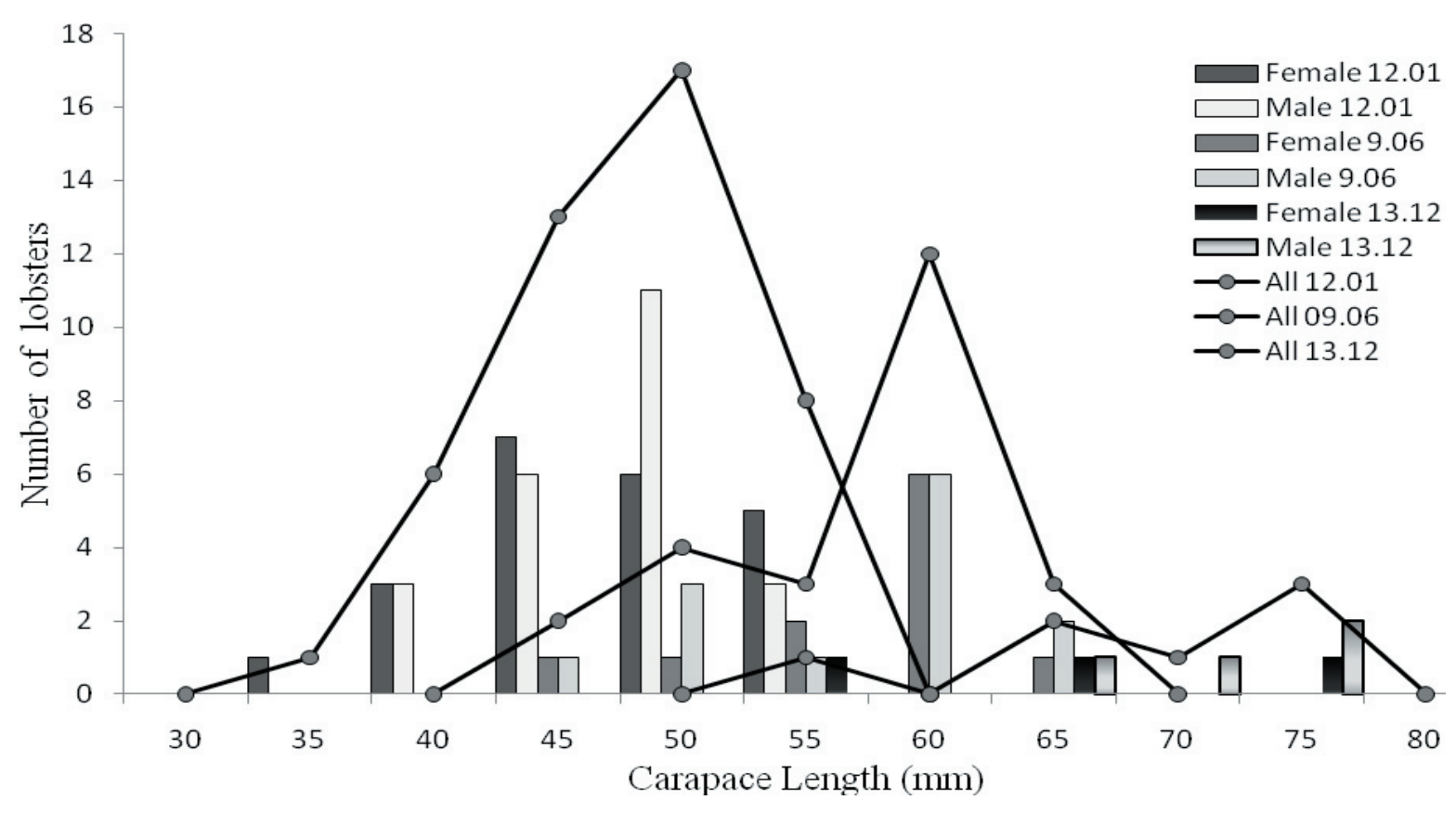

Figure 3. Size composition of the P. homarus at the aquarium trial in Mirbat in 2010.

$5350 \mathrm{~g}$, hence the mean weight of one lobster was calculated as $118.9 \mathrm{~g}$. By the middle of the year (June) the lobsters grew to an average $54.4 \pm 5.9 \mathrm{~mm} \mathrm{CL}$ and weight of $200.0 \mathrm{~g}$, and at the end in December they had attained a mean length of $66.0 \pm 7.1 \mathrm{~mm} \mathrm{CL}$, and a mean weight of $304 \pm 84.4 \mathrm{~g}$. The largest lobster reached $74.2 \mathrm{~mm}$ CL and weighed $398.7 \mathrm{~g}$. The size composition of lobsters at the start, middle and end of the aquarium trial is presented in figure 3 .

As in the previous experiment males grew faster and reached a mean CL $5 \mathrm{~mm}$ larger and weighed $27.6 \mathrm{~g}$ more in comparison with females over the same period. But an ANOVA test did not show significant differences in this case $\left(\mathrm{F}_{6.61}=0.05, \mathrm{p}<0.05\right)$; this may be due to the small numbers of the studied individuals.

The mean length increment for both sexes during 11 months was $20.7 \mathrm{~mm} \mathrm{CL}$ (45.8\%), and total mean weight increment was $185.1 \mathrm{~g}(155.7 \%)$ (see Table 1). The mean monthly increments were $1.66 \mathrm{~mm} \mathrm{CL}$ for females and $2.04 \mathrm{~mm}$ CL for males, the mean weight increment for both sexes was $16.8 \mathrm{~g}$ month ${ }^{-1}$. The mean daily weight increment was calculated as $0.55 \mathrm{~g}$ and specific growth rate (SGR) of weight attained $0.28 \%$.

It is difficult to estimate the total survival rate in this experiment because 16 lobsters were lost for obscure reasons in June. In general, the survival rate was high over the first 6 months of rearing $(86.7 \%)$ and low in subsequent months. In total it was registered that 22 lobsters $(48.9 \%)$ died, with the highest mortality rate from June to September during the summer monsoon (Fig. 4A).

A total of 117 specimens were used to calculate the carapace length-total weight relationship in $P$. homarus, for both sexes the equation was $\mathrm{W}=0.0025 \cdot \mathrm{CL}^{2.7932}\left(\mathrm{R}^{2}\right.$ $=0.97$ ).

\section{Molting and Feeding}

Twenty-seven molts were registered (Fig. 4B) during the first 3 months of the second experiment (JanuaryDecember 2010). The lobsters did not molt during April and May, with molting becoming more active in summer (June, July and September), when water temperature was low, with several molts noted from October to December.

During the first experiments 14 lobsters were fed 150-400 g chopped sardines daily. The lobsters consumed between 150 and $228 \mathrm{~g}$ per day in different months, between 10.8 to $16.2 \mathrm{~g}$ of one lobster per day. The mean daily food ration of a lobster was $3.0-4.6 \%$ of wet body weight.

In the second experiment 45 lobsters were fed 300-450 g chopped sardines daily. They consumed from 13.9 to $100 \%$ of the food (mean $74.3 \%$ ). The calculated feeding rate for individuals per day increased during the experiment with lobster growth from 6.2 to $20.2 \mathrm{~g}$. The mean daily food ration was $5.2-8.8 \%$ of wet body weight (Fig. 5).

\section{Discussion}

The environmental parameters in tanks during the experiments reflected the ambient conditions in this region of the Arabian Sea. Recorded water conditions in June-December 2009 and January-December 2010 have similar trends and were also similar to the experimental 

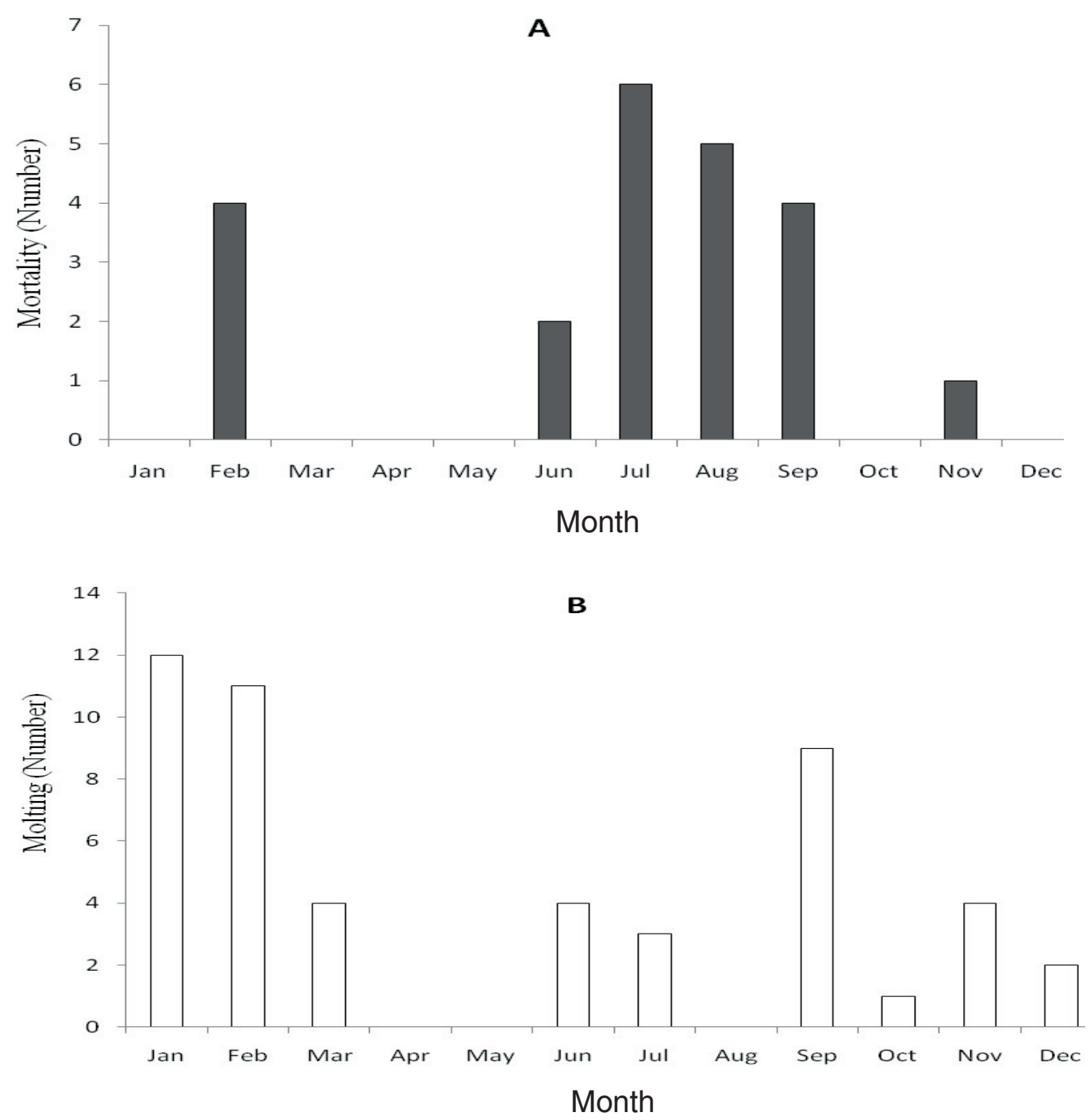

Figure 4. Mortality (A) and molting (B) of the P. homarus during experimental trial in tanks at Mirbat.

conditions of 2007 (Al-Marzouqi et al., 2009). In summary, in summer time these conditions were outside the favorable criteria for lobster culture established by Phillips et al. (1980) in which water temperature must range from 28 to $32^{\circ} \mathrm{C}$ and the salinity should be between 30 and $34 \mathrm{ppt}$ for better production. During the summer south-west monsoon (July-September) the south Oman coastal surface water temperature can decrease to $17-19^{\circ} \mathrm{C}$, while salinity is high and relatively stable all-year round (about $37.5 \mathrm{ppt}$ ). Although lobsters are able to adjust to a wide range of water temperature and salinity, these fluctuations could cause environmental stress in cultured specimens. Some investigations have shown that laboratory held lobsters grew faster at lower temperatures $\left(25-26^{\circ} \mathrm{C}\right)$ than at higher temperatures $\left(28-29^{\circ} \mathrm{C}\right)$ because of both increased molt increments and shortened intermolt periods (Kulmiye and Mavuti, 2005). Our data confirm an increase of the molting rate in summer time when the temperature is lowered, but an increase of molting also raises the risk of lobster mortality. Specifically, 17 lobsters (37.8\%) died in the 2010 summer period (June-September). It is known that the lethal level of dissolved oxygen for lobster culture ranges from 0.5 to $3.0 \mathrm{mg}^{-1} \mathrm{l}^{-1}$ (Kittaka, 1994), but such a situation was not observed during the present study. The $\mathrm{pH}$ was relatively high, and in some periods increased to about 10, which is not favorable for lobsters. This possibly indicates that the best period for lobster culture in Omani waters of the Arabian Sea is from October to May-June.

The calculated mean daily growth rate in the experiment held in May-August 2007 was $0.04 \mathrm{~mm} d a y^{-1}$, in the experiment in June -December 2009 it was also 0.04 


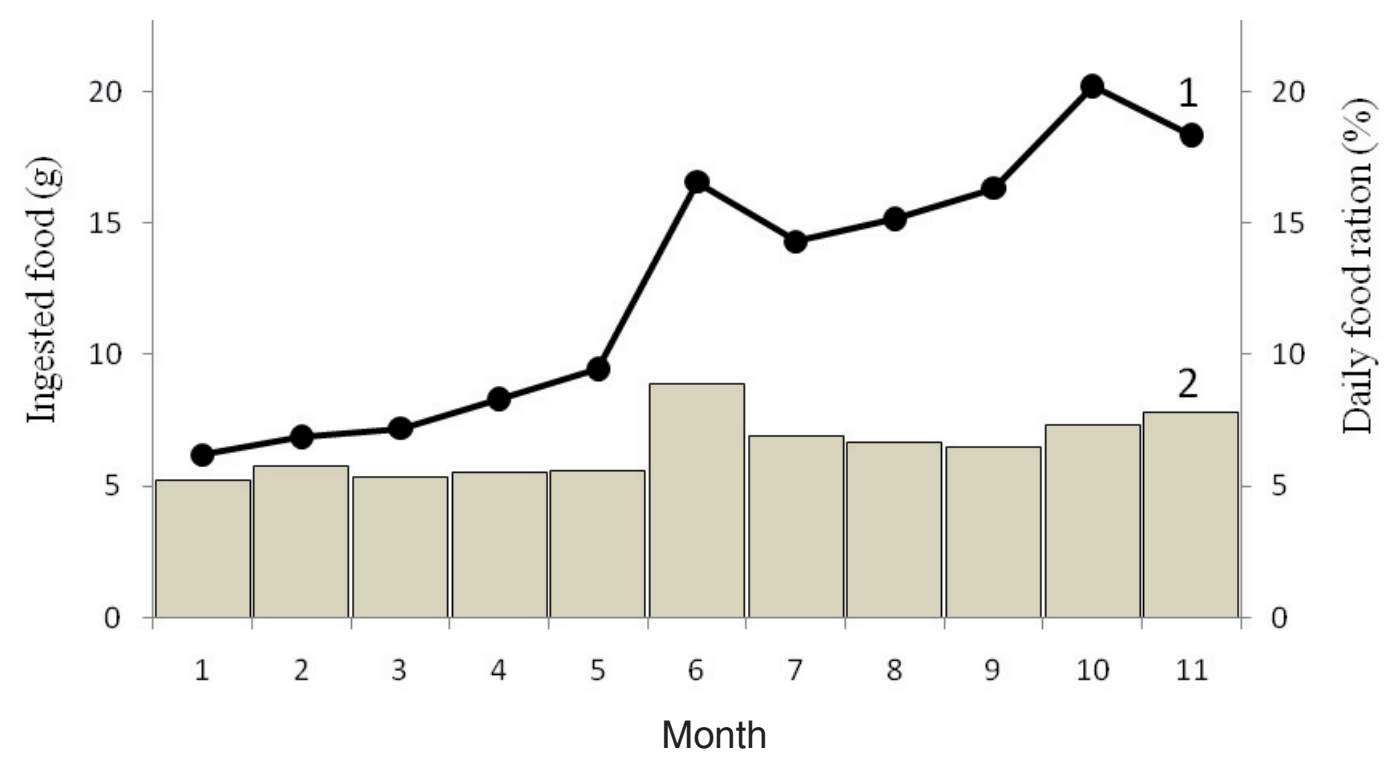

Figure 5. Food consumption during experimental rearing of the P. homarus: 1 - mean ingested food by lobster per day, 2 - daily food ration $(\%)$.

mm day ${ }^{-1}$ and in the ones conducted in January-December 2010 it was $0.06 \mathrm{~mm}^{-1} \mathrm{day}^{-1}$. It is known that the growth of the animals slows down over time. Our experimental data show higher growth rates for the lobsters in the 45-60 mm range with decreased increments in individuals longer than $60 \mathrm{~mm}$ CL. As a result, it can be recommended that lobsters are reared from $40-45 \mathrm{~mm}$ CL to the legal size of $70 \mathrm{~mm} \mathrm{CL}$. Length-weight relationship calculations show the weight of these lobsters are about 100 and $350 \mathrm{~g}$, correspondingly. In all experiments males had higher growth increments and grew faster than females.

The survival rate of lobsters during rearing can be high. In the 2007 experiment 32 out of the initial 37 lobsters survived (86.5\%), in 200913 from the initial 14 specimens survived $(92.9 \%)$, and during the first 6 months of the 2010 experiment 39 from the initial 45 animals survived $(86.7 \%)$.

To estimate outputs of the aquarium experiments at Mirbat and for the purpose of future actions in the development of lobster culture in Oman the current literature on life cycle and biological parameters of the $P$. homarus population near the coast of Oman of the Arabian Sea and data on cultivation of these lobsters in other countries of the Indian Ocean was researched.

The first attempts to culture spiny lobsters began in 1898 with the experimental hatching and rearing of the lobster larvae (phyllosoma) in Japan by Hattori and Oishi (1899). For more than 110 years many studies and practical investigations have been undertaken on different species of spiny lobsters in many countries, but in spite of numerous efforts success in the large-scale larval culture has not been achieved and is unlikely to be economically viable in the foreseeable future. A limited number of laboratories in Japan and Australia have produced several hundred juveniles for several species of Panulirus (Yamakawa et al., 1989; Kittaka and Kimura, 1989; Hart and van Barneveld, 2000; Ritar, 2001; Ritar et al., 2002, 2003). The main obstacles are the extremely long development period for the phyllosoma larvae (almost 1 year), very high and changeable requirements to the environmental and feeding conditions, frequent occurrence of bacterial diseases and very low larval survival rate. It takes up to three to four years or more under optimum conditions for spiny lobsters to reach commercial size from hatching. The long culture period required for attaining market size, particularly in comparison with some cultured finfish or shrimp species, is the main constraint to commercialization of the complete cycle of lobster culture.

A more effective suggested approach, alternative to hatchery production, is to capture settling wild lobster seed (pueruli or juveniles) in the sea and then allow their grow-out in tanks, ponds or in seacages (Chittleborough, 1974; Serfling and Ford, 1975; Radhakrishnan, 1994, 2004; Radhakrishnan and Viyayakumaran, 1990; Jeffs and James, 2001; James, 2007). Significant advances were made in lobster postlarval grow-out in Vietnam, Indonesia, Taiwan, Singapore, New Zealand and Australia. In 2006 the lobster aquaculture industry in Vietnam had more than 49,000 cages producing approximately 1,900 t of product, valued at about US\$90 million (Hung and Tuan, 2009). In Indonesia more than 1,500 small-scale farm units are established and produce about 4-5 t of lobsters per month (Priyambodo and Sarifin, 2009).

Several investigations have shown that growth and survival rates of lobsters is higher in floating sea cages when compared with land-based tanks. Sub-adult $P$. 
homarus (i.e., from 80-100 g) cultured in cages and fed with trash fish show high survival (about 75\%). After 5-8 months, they can be harvested at the marketable size of 150-300 g (Vijayakumaran and Radhakrishnan, 1984; Vijayakumaran et al. 2009; Priyambodo and Sarifin, 2009; Rao et al., 2010).

The size of sampled lobsters in Al-Wusta and Dhofar region of the Sultanate Oman in 2003-2007 (24,060 individuals) ranged between 22.6 and $127.7 \mathrm{~mm} \mathrm{CL}$ (Al-Marzouqi et al., 2009) and weight between 15 to $1350 \mathrm{~g}$. Based on von Bertalanffy growth parameters $\left(\mathrm{CL}_{\text {inf }}=128.9 \mathrm{~mm}, \mathrm{~K}=0.33\right.$ and $\left.\mathrm{t}_{0}=-0.35\right)$ estimated by Al-Marzouqi et al. (2007) we calculated the age of the smallest juvenile lobsters ( $22 \mathrm{~mm} \mathrm{CL})$ in the catches as 2.5 months. The percent of juvenile lobsters $(<40 \mathrm{~mm})$ in catches is insignificant, the size of sub-adult lobsters in traps is usually more than $45 \mathrm{~mm}$ CL weighing more $100 \mathrm{~g}$. This corresponds with the initial size of lobsters used in our experiment in 2010 (45.3 mm CL, 118.9 g). Estimated age of these individuals according to the von Bertalanffy parameters mentioned above was about 1 year. According to Al-Marzouqi et al. (2007) P. homarus reaches a maximum size at the age of 8-10 years. During 11 months of rearing in our tanks the lobster size increased to $66.0 \mathrm{~mm}$ and $304.0 \mathrm{~g}$. Calculations using the von Bertalanffy equation (Al-Marzouqi et al., 2007) showed that the age of lobsters at $70 \mathrm{~mm} \mathrm{CL}$ is 2.02 years. Therefore, it needs approximately one year for $P$. homarus growing in captivity in Oman from initial sub-adults of 40-45 mm CL and weight of about $100 \mathrm{~g}$ to reach a legal size of $70 \mathrm{~mm} \mathrm{CL}$ and weight of about $350 \mathrm{~g}$. According to estimates from Al-Marzouqi et al. (2007) the lobsters reach the length at first maturity of $65.7 \mathrm{~mm} \mathrm{CL}$ at the age of approximately two years, so the targeted growout period in captivity (about one year) is appropriate to obtain mature females in Oman.

In our 2010 experiment weight increments of the $P$.

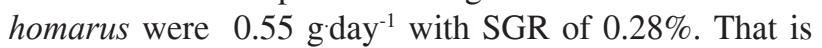
low in comparison with data reported from India and Indonesia where growth rates were $0.75-0.85 \mathrm{~g}^{-d_{a y}}{ }^{-1}$ and SGR 0.50-0.58\% (Kaleemur et al., 1997; Radhakrishnan and Vijayakumaran, 1990; Rao et al., 2010; Srikrishnadhas et al., 1983). Possibly, the slower growth rate of lobsters in captivity in indoor tanks at Mirbat can be attributed to low water temperature $\left(<20^{\circ} \mathrm{C}\right)$ during the summer time and isufficient food. Nevertheless the present study demonstrated the possibility of the development of lobster culture in Oman.

\section{Conclusion}

Lobsters are a very important natural and economic resources in Oman. Currently, stock recovery is a serious problem that requires not only good conservation measures, but also the development of their artificial cultivation. It is known that young lobsters have a very high mortality rate in nature $(Z=2.07)$. (Al-Marzouqi et al. (2007), calculated values show that just $13 \%$ of lobsters may survive during the second year after settling on the sea bed. On the contrary, our data combined with current literature data show that in captivity in tanks and sea cages survival rates can be significantly higher (about 70-75\%). This suggests that farming of lobsters not only can improve the commercial production but could also help in enhancing the natural stock. The current fishery management in Oman banned the exploitation of juvenile lobsters. But in the case of successful results of the experimental lobster growing in sea cages it will be possible to recommend that one Omani company organizes the collection of sub-adult lobsters and their fattening in sea cages (from October to June) for commercial production. In addition they will release all reared egg-bearing females to the sea to facilitate the restoration natural stocks. Results of many investigations indicate that sea cage culture is a biologically feasible way of growing juvenile lobsters to market size. In order to develop the possibility of lobster culture in Oman we propose the continuation of research in floating sea cages.

\section{Acknowledgments}

We are grateful to H.E. Dr. Hamed Al-Oufi, the Undersecretary of Ministry of Agriculture and Fisheries Wealth and Dr. Saoud Al-Habsi, the Director General of the Fisheries Research, for the opportunity provided to carry-out the aquarium component of the Lobster Project and financial support. We are also thankful to Mr. Salem Al-Ghassani, formerly Director of Fisheries Research Center-Salalah, for his kind support in fulfilling this project. We express our thanks to the technical staff at (MAU) Mr. Basheer and Mr. Salem Khoom who participated in laboratory work related to the project.

\section{References}

Al-Abdessalaam, T.Z.S. 1995. Marine Species of the Sultanate Oman: An Identification Guide. Ministry of Aquaculture and Fisheries, Marine Science and Fisheries Centre, Sultanate of Oman. Muscat Printing Press. 412pp.

Al-Abdulsalaam, T.Z. 1989. Effects of exploitation on life history characteristics of spiny lobster populations (Panulirus homarus) off Oman. M.Sc. Thesis, Oregon State University, Corvallis, Oregon, USA.

Al-Marzouqi, A., A. Al-Nahdi, N. Jayabalan, and J.C. Groeneveld. 2007. An assessment of the spiny lobster Panulirus homarus fishery in Oman - another decline in the Western Indian Ocean? Western Indian Ocean Journal of Marine Sciences 6:159-174.

Al-Marzouqi, A., N. Jayabalan, A. Al-Nahdi, and A. Al-Hosni. 2007. Lobster Fisheries in the Sultanate of Oman Project Phase I (2002-2005). Ministry of Fisheries Wealth, Marine Science and Fisheries Centre. 50pp.

Al Marzouqi, A., J.C. Groeneveld, A. Al-Nahdi, N. Jayabalan, and A. Al-Hosni. 2009. Lobster Fisheries 
in the Sultanate of Oman Project Phase II (20052008). Ministry of Fisheries Wealth, Marine Science and Fisheries Centre. 90pp.

Anonymous. 2006. Fisheries Statistics Book (2005) for the Sultanate of Oman. Directorate of General Planning and Investment Promotion. Statistics and Information Department. Ministry of Agriculture and Fisheries, Muscat, 240pp.

Anonymous. 2010. Fisheries Statistics Book (2009) for the Sultanate of Oman. Directorate of General Planning and Investment Promotion. Statistics and Information Department. Ministry of Agriculture and Fisheries, Muscat, 209pp.

Chittleborough, R.G. 1974. Review of prospects of rearing rock lobsters. Australian Fisheries 33:4-8.

Hart, P. and R. van Barneveld. 2000. Rock lobster enhancement and aquaculture in Australia. In: 2000 Australian Aquaculture Yearbook, P. Shelley (Editor), 39-41. National Aquaculture Council, Executive Media Pty Ltd, Melbourne.

Hattori, T. and Y. Oishi. 1899. Hatching experiment on Ise lobster. Report of the Imperial Fisheries Institute 1: 76-132.

Hung, L.V. and L.A. Tuan. 2009. Lobster seacage culture in Vietnam. In: Spiny Lobster Aquaculture in the Asia-Pacific Region, K.C. Williams (Editor), 10-17. Proceedings of an International Symposium, Nha Trang, Vietnam, 9-10 December 2008. ACIAR Proceedings 132, Canberra.

James, P. 2007. Lobsters do well in sea cages: Spiny lobster on-growing in New Zealand. Bulletin of Fisheries Research 20:69-71.

Jeffs, A.G. and P. James. 2001. Sea-cage culture of the spiny lobster Jasus edwardsii in New Zealand. Marine and Freshwater Research 52:1419-1424.

Kaleemur, R.M.D., M.T.L. Joseph, and B. Srikrishnadhas. 1997. Growth performance of spiny lobster Panulirus homarus (Linnaeus) under mass rearing. Journal of Aquaculture in the Tropics 12:243-253.

Kittaka, J. 1994. Culture of phyllosomas of spiny lobster and its application to studies of larval recruitment and aquaculture. Crustaceana 66:258-270.

Kittaka, J. and K. Kimura. 1989. Culture of the Japanese spiny lobster Panulirus japonicus from egg to juvenile stage. Nippon Suisan Gakkaishi 55:963-970.

Kulmiye A.J. and K.M. Mavuti. 2005. Growth and moulting of captive Panulirus homarus in Kenya, western Indian Ocean. New Zealand Journal of Marine and Freshwater Research 39:539-549.

Mohan, R. 1997. Size structure and reproductive variation of the spiny lobster Panulirus homarus over a relatively small geographic range along the Dhofar coast in the Sultanate of Oman. Marine and Freshwater Research 48:1085-1091.

Phillips, E.S., J.S. Cobb, and R.W. George. 1980. General Biology. In: The Biology and Management of Lobster,
Vol. 1., J.S. Cobb and E.S. Phillips (Editors), 1-82. Press,New York.

Priyambodo, B. and Sarifin. 2009. Lobster aquaculture industry in Eastern Indonesia: present status and prospects. In: Proceedings of an International Symposium Spiny Lobster Aquaculture in the AsiaPacific Region, Kevin C. Williams (Editor), 36-45, Nha Trang, Vietnam, 9-10 December 2008. ACIAR Proceedings 132, Canberra.

Radhakrishnan, E.V. 1994. Commercial prospects for farming spiny lobsters. Aquaculture towards the 21st century. In: Proceedings of the Infofish Aquatech 94 Conference, 96-102. Colombo, Sri Lanka, 27-31 August 1994.

Radhakrishnan, E.V. 2004. Prospects for grow-out of the spiny lobster, Panulirus homarus in indoor farming system. In: Program and Abstracts, 7th International Conference and Workshop on Lobster Biology and Management, Hobart, Tasmania, 8-13 February 2004.

Radhakrishnan, E.V. and M. Vijayakumaran. 1990. An assessment of potential of spiny lobster culture in India. CMFRI Bulletin 44:416-427.

Rao G.S., R.M. George, M.K. Anil, K.N. Saleela, S. Jasmine, H.J. Kingsly, and G.H. Rao. 2010. Cage culture of the spiny lobster Panulirus homarus (Linnaeus) at Vizhinjam, Trivandrum along the south-west coast of India. Indian Journal of Fisheries 57:23-29.

Ritar, A.J. 2001. The experimental culture of phyllosoma larvae of southern rock lobster (Jasus edwardsii) in a flow-through. Aquacultural Engineering 24:149-156.

Ritar, A.J., C.W. Thomas, and A.R. Beech. 2002. Feeding Artemia and shellfish to phyllosoma larvae of southern rock lobster (Jasus edwardsii). Aquaculture 212: 183-94.

Ritar, A.J., G.G. Smith, G.A. Dunstan, M.R. Brown, and P.R. Hart. 2003. Artemia prey size and mode of presentation: effects on the survival and growth of phyllosoma larvae of southern rock lobster (Jasus edwardsii). Aquaculture International 11: 163-180.

Serfling, A.A. and R.F. Ford. 1975. Ecological studies of the peurulus larvae stages of the California spring lobster Panulirus interruptus. Fishery Bulletin 73:360377.

Srikrishnadhas, B.V., V. Sunderraj, and M.D. Kuthalingam. 1983. Cage culture of spiny lobster Panulirus homarus. In: Proceedings of the National Seminar on Cage and Pen Culture, pp. 103-106, Fisheries College and Research Institute, Tuticorin, India.

Vijayakumaran, M. and E.V. Radhakrishnan. 1984. Effect of eyestalk ablation in the spiny lobster Panulirus homarus (Linnaeus): 2. On food intake and conversion. Indian Journal of Fisheries 31:148-155.

Vijayakumaran, M., R. Venkatesan, T.S. Murugan, T.S. Kumar, D.K. Jha, M.S. Remany, J.M.L. Thilakam, S.S. Jahan, G. Dharani, S. Kathiroli, and K. Selvan. 2009. Farming of the spiny lobsters in sea cages in India. 
New Zealand Journal of Marine and Freshwater Research 43:623-634.

Yamakawa, T., M. Nishimura, H. Matsuda, A. Tsujigado, and N. Kamiya. 1989. Complete larval rearing of the
Japanese spiny lobster Panulirus japonicus. Nippon Suisan Gakkaishi 55:745.

Zar, J.H. 1984. Biostatistical Analysis. Englewood Cliffs, N.J: Prentice-Hall Inc. 620pp.

Received: February 12, 2012

Accepted: May 30, 2012 